\title{
Flexural strength of fluorapatite-leucite and fluorapatite porcelains exposed to erosive agents in cyclic immersion
}

\author{
Peerapong JUNPOOM ${ }^{1}$, Boonlert KUKIATTRAKOON ${ }^{2}$, Chanothai HENGTRAKOOL ${ }^{2}$
}

1- DDS, MSc, Section of Dental Public Health, Huay Yod Hospital, Trang, Thailand.
2- DDS, MSc, Associate Professor, Department of Conservative Dentistry, Faculty of Dentistry, Prince of Songkla University, Hat Yai, Songkhla, Thailand.
3- DDS, MSc, PhD, Assistant Professor, Department of Conservative Dentistry, Faculty of Dentistry, Prince of Songkla University, Hat Yai, Songkhla, Thailand.

Corresponding address: Assoc. Prof. Boonlert Kukiattrakoon - Department of Conservative Dentistry - Faculty of Dentistry - Prince of Songkla University Hat Yai - Songkhla - Thailand - Phone: +66-74-28-7703 - Fax: +66-74-429877 - e-mail: boonlert.k@psu.ac.th

Received: June 17, 2009 - Modification: January 23, 2010 - Accepted: February 10, 2010

\section{ABSTRACT}

\begin{abstract}
$\mathrm{O}$ bjective: The aim of this study was to evaluate the flexural strength of two porcelain materials (IPS d.SIGN and IPS e.max Ceram) exposed to erosive agents. Material and Methods: One hundred and twenty bar-shaped specimens were made from each of fluorapatite-leucite porcelain (IPS d.SIGN) and fluorapatite porcelain (IPS e.max Ceram) and divided into 8 groups of 15 specimens each. Six groups were alternately immersed in the following storage agents for $30 \mathrm{~min}$ : deionized water (control), citrate buffer solution, pineapple juice, green mango juice, cola soft drink and $4 \%$ acetic acid. Then, they were immersed for $5 \mathrm{~min}$ in deionized water at $37^{\circ} \mathrm{C}$. Seven cycles were completed, totalizing 245 min. A $7^{\text {th }}$ group was continuously immersed in $4 \%$ acetic acid at $80^{\circ} \mathrm{C}$ for $16 \mathrm{~h}$. The final, $8^{\text {th }}$, group was stored dry at $37^{\circ} \mathrm{C}$ for $245 \mathrm{~min}$. Three-point bending tests were performed in a universal testing machine. The data were analyzed statistically by 2-way ANOVA, Tukey's HSD test and t-test at significance level of 0.05. Results: The flexural strengths of all groups of each porcelain after exposure to erosive agents in cyclic immersion did not differ significantly $(p>0.05)$. For both types of porcelain, dry storage at $37^{\circ} \mathrm{C}$ yielded the highest flexural strength, though without significant difference from the other groups $(p>0.05)$. The flexural strengths of all groups of fluorapatite porcelains were significantly higher $(p<0.05)$ than those of the fluorapatite-leucite porcelains. Conclusions: This study demonstrated that the erosive agents evaluated did not affect the flexural strength of the tested dental porcelains.
\end{abstract}

Key words: Dental porcelain. Erosion. Immersion. Juices. Soft drinks.

\section{INTRODUCTION}

Porcelains are highly esthetic materials extensively used in dentistry to construct various types of restorations and prostheses such as porcelain fused to metal crowns, veneers, inlays, onlays and all ceramic restorations. They fulfill the esthetic and functional demands of the patients by their superior properties when compared to other restorative materials ${ }^{26}$. The new glass ceramics (IPS d.SIGN; Ivoclar Vivadent AG, Schaan, Liechtenstein) have become popular for porcelain-fused-to-metal restorations. IPS d.SIGN is a new type feldspathicbased porcelain containing dispersed fluorapatite and leucite crystals in a feldspathic glassy matrix ${ }^{10}$. The leucite crystals $(<3 \mu \mathrm{m})$ present in the IPS d.SIGN porcelain also contribute to the overall strength $^{28}$. Recently, the new all ceramic systems (IPS e.max; Ivoclar Vivadent AG, ) have been introduced into the market. IPS e.max Ceram is a veneering porcelain of this system which is a feldspathic-based porcelain having a microstructure unlike IPS d.SIGN. This porcelain only consists of dispersed fluorapatite crystals in a feldspathic glassy matrix; thus, having a microstructure unlike that of any other commercially available dental porcelains ${ }^{28}$. Fluorapatite crystals, 2-5 $\mu \mathrm{m}$ in length and $300 \mathrm{~nm}$ in diameter of needle-like 
morphology, are known to be contained in natural bone and teeth. These very small crystals in dental microstructures result in very special optical properties such as translucence and opalescence, which also result the same properties as in dental restorations ${ }^{11}$.

Despite the outstanding esthetic quality of the porcelains, the most serious problem of this material is its susceptibility to fractures ${ }^{9,15}$. Porcelains exhibit inherent flaws or defects on the surface and body. These characteristics impair their physical properties such as surface roughness, surface hardness, strength ${ }^{3,6}$ and influence the clinical success and failure of porcelain restorations ${ }^{7}$. Crack propagation and degradation of dental porcelains occur when porcelains are exposed to aqueous solutions or erosive agents ${ }^{1}$. These phenomenons take place as a result of selective leaching of alkaline ions. Alkaline metal ions are far less stable in the glass phase than in the crystalline phase ${ }^{1}$. Therefore, some alkaline ions in porcelains were leached after

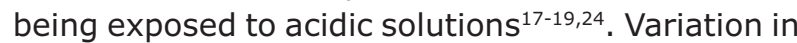
$\mathrm{pH}$, solution chemistry, wear and mechanical load makes the oral cavity a complex environment ${ }^{1}$. Environmental conditions may also damage resistance to surface and bulk degradation of porcelains. Consequences of porcelain degradation include coarseness of exposed surface ${ }^{4,24}$, promoting plaque accumulation ${ }^{1,2,4,24}$ and wear to antagonist materials ${ }^{1}$. Furthermore, increasing of surface roughness of porcelains may decrease strength ${ }^{9,15}$.

Many people frequently consume acidic food, sour fruits and drinks. This consuming habit relates to a high incidence of dental erosion $14,16,23,27$. The potential erosive effect of these acidic food and beverages on enamel occurs primarily by the dissolution of apatite crystals ${ }^{12,16,20}$. However, their effect on the porcelain restorations has not been clearly documented. Therefore, the present in vitro study was designed to evaluate changes of the flexural strength and surface of fluorapatite-leucite and fluorapatite porcelains after being exposed to erosive agents (pineapple juice, green mango juice, coca soft drink, citrate buffer solution and $4 \%$ acetic acid) in cyclic immersion. The null hypothesis was that there was no significant difference in flexural strength of each type of dental porcelain tested after being exposed to erosive agents.

\section{MATERIAL AND METHODS}

\section{Specimen Preparation}

Two commercial dentin shade A3 porcelain powders were used: IPS d.SIGN and IPS e.max Ceram (Ivoclar Vivadent AG) (Figure 1). IPS d.SIGN and IPS e.max Ceram are indicated to be used as veneering porcelain for porcelain fused to metal and all ceramic restorations, respectively. One hundred and twenty bar specimens from each of the 2 porcelains were fabricated using the $26.0 \times 6.0 \times 3.0$ $\mathrm{mm}$ silicone mold (Provil novo putty; Heraeus Kulzer GmbH, D-63450 Hanau, Germany). The porcelain powders were mixed with deionized water, filled in the silicone mold and condensed with a condenser (Ceramosonic II; Shofu Inc, Higashiyama-ku, Kyoto, Japan). The specimens were then fired according to the manufacturer's instructions (Table 1). After firing, the specimens were polished (model Phoenix 4000; Buehler GmbH, 40599 Düsseldorf, Germany) under running water using 600- and 1,200-grit silicon carbide paper (3M ESPE, St. Paul, MN, USA) to the dimensions of $25.0 \times 5.0 \times 2.0 \mathrm{~mm}$, following the guidelines of the ISO 6872 standard $^{13}$. Then, the specimens were ultrasonically cleaned in distilled water for $10 \mathrm{~min}$, and subjected to selfglazing according to the manufacturer's instructions (Table 1).

\section{Erosive Agents Exposure}

The porcelain bars were divided into 8 groups of 15 specimens each. Subsequently, the specimens were alternately immersed in $25 \mathrm{~mL}$ of an erosive agent for $30 \mathrm{~min}$ and in $25 \mathrm{~mL}$ of deionized water for 5 min for 7 cycles at $37^{\circ} \mathrm{C}$. This amount of erosive agent $(25 \mathrm{~mL})$ was a sufficient volume to completely cover the specimen. In order to maintain the original $\mathrm{pH}$ level of the erosive agent, the agents were refreshed every cycle throughout the experiment. The same protocol was used with different types of 5 erosive solutions included in the study (citrate buffer solution, pineapple juice, green mango juice, cola soft drink and $4 \%$ acetic acid; see Figure 2) and deionized water (control). The specimens' immersion protocol simulated an

\begin{tabular}{|c|c|c|c|}
\hline Porcelain & Type & Composition (wt \%) & Manufacturer \\
\hline IPS d.SIGN & $\begin{array}{c}\text { Fluorapatite-leucite } \\
\text { porcelain }\end{array}$ & $\begin{array}{c}\mathrm{SiO}_{2} 50-65, \mathrm{Al}_{2} \mathrm{O}_{3} 8-20, \mathrm{Na}_{2} \mathrm{O} 4-12 \\
\mathrm{~K}_{2} \mathrm{O} 7-13, \mathrm{CaO} 0.2-5, \mathrm{~F} \mathrm{0.1-3,} \mathrm{ZnO} \\
2-3\end{array}$ & $\begin{array}{c}\text { Ivoclar Vivadent AG, } 9494 \text { Schaan, } \\
\text { Liechtenstein } \\
(\text { Lot N. H28470) }\end{array}$ \\
\hline IPS e.max Ceram & Fluorapatite porcelain & $\begin{array}{c}\mathrm{SiO}_{2} 60-65, \mathrm{Al}_{2} \mathrm{O}_{3} 8-12, \mathrm{Na}_{2} \mathrm{O} \text { 6-9 } \\
\mathrm{K}_{2} \mathrm{O} \text { 6-8, } \\
\mathrm{ZnO}_{2}-3, \mathrm{CaO} \text { 1-3, F 1-2, } \\
\mathrm{P}_{2} \mathrm{O}_{5} \text { 0.1-1 }\end{array}$ & $\begin{array}{c}\text { Ivoclar Vivadent AG, } 9494 \text { Schaan, } \\
\text { Liechtenstein } \\
\text { (Lot N.H18984) }\end{array}$ \\
\hline
\end{tabular}

Figure 1- Porcelains used in the present study 
individual eating acidic food, sour fruits and drinks. Total immersion time was 245 min. Seventh group was continuously immersed in $4 \%$ acetic acid at $80^{\circ} \mathrm{C}$ for $16 \mathrm{~h}$ (as modified from ISO $6872^{13}$ ) in order to examine the extensive effect which could occur. A $8^{\text {th }}$ group was kept dry at $37^{\circ} \mathrm{C}$ for $245 \mathrm{~min}$ in order to compare the effect of moisture condition. After the immersion sequence was completed, the specimens were rinsed with deionized water, blotted dry and subjected to flexural strength testing.

\section{Flexural Strength Measurements}

The flexural strength was measured with the universal testing machine (model LRX-plus; Ametek Lloyd Instruments, Farnborough, Hampshire, UK). Bar-shaped specimens were centered and placed on two steel spheres (1.6 $\mathrm{mm}$ in diameter) of a supporter part positioned $12 \mathrm{~mm}$ apart from each other. Three point bending tests were carried out using a $250 \mathrm{~N}$ load cell at crosshead speed $0.25 \mathrm{~mm} / \mathrm{min}$. The load at failure was recorded in Newton and converted to flexural strength in $\mathrm{MPa}\left(3 \mathrm{WL} / 2 \mathrm{BD}^{2} ; \mathrm{W}=\right.$ failure load, $\mathrm{L}=$ span length, $B=$ specimen's width, and $D=$ specimen's thickness).

\section{Statistical Analysis}

Two-way ANOVA was analyzed to measure statistically significant differences among the types of erosive agents and the type of porcelains after being exposed to erosive agents. Tukey's Honestly Significant Difference (HSD) tests were used for post hoc comparisons $(\alpha=0.05)$. The $t$-test was used for comparing the flexural strength between the two types of porcelain for each erosive agent ( $\alpha=0.05)$.

\section{RESULTS}

The flexural strength values of the two types of porcelain were showed in Table 2. ANOVA results showed that the interaction between the two variables (type of porcelain and erosive agent) found statistically significant difference $(p=0.02)$. Between the two dental porcelains, a statistically significant difference was also found $(p=0.01)$, but none was found among the types of erosive agents $(p=0.46)$.

When comparing the mean flexural strength values between the porcelains for each group, the results of the $t$-test showed that all IPS e.max Ceram groups yielded a significantly higher mean flexural strength $(p<0.05)$ than that of IPS d.SIGN groups.

\begin{tabular}{|c|c|c|}
\hline Erosive agent & Form & Manufacturer \\
\hline Citrate buffer solution & Instant & BDH Laboratory Supplies, Poole, England \\
\hline \multicolumn{3}{|l|}{$\mathrm{pH} 4.99 \pm 0.01$} \\
\hline $100 \%$ pineapple juice & Instant & $\begin{array}{c}\text { Tipco Foods Co. Ltd., Prajuabkirikhan, } \\
\text { Thailand }\end{array}$ \\
\hline \multicolumn{3}{|l|}{$\mathrm{pH} 3.64 \pm 0.01$} \\
\hline Green mango juice & Prepared from fresh green mango & _ \\
\hline \multicolumn{3}{|l|}{$\mathrm{pH} 2.39 \pm 0.01$} \\
\hline Cola soft drink & Instant & Hadthip Ltd, Songkhla, Thailand \\
\hline \multicolumn{3}{|l|}{$\mathrm{pH} 2.41 \pm 0.06$} \\
\hline $4 \%$ acetic acid & Diluted from $100 \%$ acetic acid & Merck KGaA, Darmstadt, Germany \\
\hline $\mathrm{pH} 2.47 \pm 0.01$ & & \\
\hline
\end{tabular}

Figure 2- Erosive agents used in the present study

Table 1- Firing schedules for the porcelains used in the present study

\begin{tabular}{ccccccc}
\hline Porcelain & & $\begin{array}{c}\text { Starting } \\
\text { temperature }\left({ }^{\circ} \mathbf{C}\right)\end{array}$ & $\begin{array}{c}\text { Heating rate } \\
\left({ }^{\circ} \mathbf{C} / \mathbf{m i n}\right)\end{array}$ & $\begin{array}{c}\text { Vacuum } \\
\text { temperature }\left({ }^{\circ} \mathbf{C}\right)\end{array}$ & $\begin{array}{c}\text { Firing } \\
\text { temperature }\left({ }^{\circ} \mathbf{C}\right)\end{array}$ & $\begin{array}{c}\text { Holding time } \\
(\mathbf{m i n})\end{array}$ \\
\hline IPS d.SIGN & Dentine & 403 & 60 & $450-909$ & 910 & 1 \\
& Glaze & 403 & 60 & $450-829$ & 830 & 0 \\
IPS e.max & Dentine & 403 & 50 & $450-849$ & 850 & 0 \\
Ceram & Glaze & 403 & 50 & $450-799$ & 800 & 0 \\
\hline
\end{tabular}


Table 2- Mean flexural strength \pm standard deviations (SD) of IPS d.SIGN and IPS e.max Ceram

\begin{tabular}{lcc}
\hline Group & \multicolumn{2}{c}{ Mean flexural strength (MPa) \pm SD } \\
& IPS d.SIGN & IPS e.max Ceram \\
\hline Deionized water (control) & $48.41 \pm 7.04^{\mathrm{a}}$ & $71.07 \pm 12.16^{\mathrm{a}}$ \\
\hline Citrate buffer solution & $51.48 \pm 10.82^{\mathrm{b}}$ & $67.69 \pm 12.73^{\mathrm{b}}$ \\
\hline Pineapple juice & $51.06 \pm 9.57^{\mathrm{c}}$ & $64.28 \pm 14.98^{\mathrm{c}}$ \\
\hline Green mango juice & $47.78 \pm 13.18^{\mathrm{d}}$ & $77.05 \pm 9.58^{\mathrm{d}}$ \\
\hline Cola soft drink & $53.25 \pm 9.43^{\mathrm{e}}$ & $63.59 \pm 10.66^{\mathrm{e}}$ \\
\hline $4 \%$ Acetic acid & $52.37 \pm 9.49^{\mathrm{f}}$ & $65.95 \pm 12.17^{\mathrm{f}}$ \\
\hline $4 \%$ Acetic acid, $16 \mathrm{~h}$ & $50.59 \pm 7.82^{\mathrm{g}}$ & $66.54 \pm 11.14^{\mathrm{g}}$ \\
\hline Dry condition & $55.3 \pm 12.63^{\mathrm{h}}$ & $78.60 \pm 11.97^{\mathrm{h}}$ \\
\hline
\end{tabular}

${ }^{a-h}$ Same superscript letters in columns indicate no significant difference (Tukey's HSD test; $\alpha=0.05$ ).

\section{DISCUSSION}

The results of this study support acceptance of the null hypothesis, as the flexural strength of both porcelains was not affected by the erosive agents. It is noticed that the highest flexural strength was found in the dry condition group (stored at $37^{\circ} \mathrm{C}$ ) of both porcelains and decreased in all groups when the porcelains were immersed in erosive agents as well as in water. The possible explanation for these results could be the effect of glazing in determining flexural strength values.

Porcelains, by nature, exhibit inherent flaws or defects on their surface and internal body. These flaws could impair their physical properties. However, the surface flaws are covered by the glazes, either self-glazing or overglazing. Re-firing the porcelain prior to final restoration produces a self-glaze layer. This layer may increase the strength of the porcelain restoration from two possible mechanisms ${ }^{8}$. Firstly, when the restoration is heated, the self-glaze layer fills in surface flaws, reducing their depth and blunting the flaw tips. This should increase strength because, for given porcelains, strength increases with decreasing sharpness and flaw depth. Secondly, for feldspathicbased porcelains, the self-glaze layer has a lower coefficient of thermal expansion than the leuciterich interior. This places the outer surface in compression when cooled. The compressive stress state diminishes the local tensile stress produced from applied loading at surface flaws, thereby needing application of increased load to initiate flaw propagation from the external surface.

The IPS e.max Ceram had higher flexural strength than the IPS d.SIGN in all groups. A possible explanation for this result could be the microstructure of these porcelains ${ }^{11}$. The IPS d.SIGN, feldspathic-based porcelain, is unique and distinct from other porcelains since its microstructure consists of fluorapatite crystal phases in addition to having leucite particles in a feldspathic glassy matrix ${ }^{10}$, while the IPS e.max Ceram consists of only dispersed fluorapatite crystals in a feldspathic glassy matrix ${ }^{28}$. In feldspathic-based porcelains, the leucite particles contract more than the surrounding glass upon cooling. Above a critical particle size, the stresses created during cooling can induce microcracks circumferential to the leucite particles ${ }^{22}$. Previous studies have documented that the size of leucite particles in feldspathic porcelain increases during heat treatment within the normal porcelain firing range ${ }^{5,21}$. This can increase the probability of microcracking ${ }^{22}$. It is possible that microcracking occurred during the self-glaze treatment. In contrast to fluorapatite porcelains, the fluorapatite phase particles are needle-like and contribute to high flexural strength as well as high chemical durability ${ }^{11}$.

The erosive agents used in this present study, pineapple juice and green mango juice, are favorite sour fruit juices in many Asia countries. They consist of citric acid and other organic acid $12,14,16$, which give an acidic $\mathrm{pH}$. However, in the present study, these juices did not affect the flexural strength of the tested porcelain after immersion, which do not agree with the findings of previous studies that showed an impact of acidic agents on porcelains ${ }^{17-19,24}$. This study was a short-term experiment and could be the reason to explain why there was no significant difference among the acidic agents and this aspect should be explored. So, a long-term evaluation of the effect of erosive agents on porcelains is required.

It must be noted that there are some limitations to this present study. This study did not consider the different conditions found in the oral environment. For example, the presence of water, temperature change, the $\mathrm{pH}$ level and the role of saliva ${ }^{25}$ in the oral cavity may considerably influence strengths of restorations. In addition, the present study evaluated only fluorapatite-leucite and fluorapatite 
porcelains. Further studies are required to investigate the effect on other porcelains.

\section{CONCLUSIONS}

Within the limitations of this study, the flexural strengths of the porcelains (fluorapatite-leucite and fluorapatite porcelains) after exposure to erosive agents in cyclic immersion were not significantly different. For both types of porcelain, dry storage at $37^{\circ} \mathrm{C}$ yielded the highest flexural strength, though without significant difference from the other groups. The flexural strengths of all groups of fluorapatite porcelains were significantly higher than those of the fluorapatite-leucite porcelains.

\section{ACKNOWLEDGEMENTS}

This study is supported in part by a grant from the Graduate School, Prince of Songkla University.

\section{REFERENCES}

1- Anusavice KJ. Degradability of dental ceramics. Adv Dent Res. 1992;6:82-9.

2- Clayton JA, Green E. Roughness of pontic materials and dental plaque. J Prosthet Dent. 1970;23(4):407-11.

3- De Jager N, Feilzer AJ, Davidson CL. The influence of surface roughness on porcelain strength. Dent Mater. 2000;16(6):381-8.

4- Demirhanoglu ŞT, Şahin E. Effect of topical fluorides and citric acid on overglazed and autoglazed porcelain surfaces. Int J Prosthodont. 1992;5(5):434-40.

5- Fairhurst CW, Anusavice KJ, Hashinger DT, Ringle RD, Twiggs SW. Thermal expansion of dental alloys and porcelains. J Biomed Mater Res. 1980;14(4):435-46.

6- Fischer $\mathrm{H}$, Schäfer M, Marx R. Effect of surface roughness on flexural strength of veneer ceramics. J Dent Res. 2003;82(12):972-5.

7- Goodacre CJ, Bernal G, Rungcharassaeng K, Kan JY. Clinical complications in fixed prosthodontics. J Prosthet Dent. 2003;90(1):31-41. 8- Griggs JA, Thompson JY, Anusavice KJ. Effects of flaw size and autoglaze treatment on porcelain strength. J Dent Res. 1996;75(6):1414-7. 9- Haselton DR, Diaz-Arnold AM, Hillis SL. Clinical assessment of highstrength all-ceramic crowns. J Prosthet Dent. 2000;83(4):396-401. 10- Höland W, Rheinberger V, Apel E, Van 't Hoen C, Höland M, Dommann A, et al. Clinical applications of glass-ceramics in dentistry. J Mater Sci Mater Med. 2006;17(11):1037-42.
11- Höland W, Rheinberger V, Wegner S, Frank M. Needle-like apatiteleucite glass-ceramic as a base material for the veneering of metal restorations in dentistry. J Mater Sci Mater Med. 2000;11(1):11-7.

12- Imfeld T. Dental erosion: definition, classification and links. Eur J Oral Sci. 1996;104(2):151-5.

13- International Organization for Standartization. ISO 6872: Dental ceramic. Geneva: The Organization; 1995.

14- Jaeggi T, Lussi A. Prevalence, incidence and distribution of erosion. Monogr Oral Sci. 2006;20:44-65.

15- Kelly R, Giordano R, Pober R, Cima MJ. Fracture surface analysis of dental ceramics: clinically failed restorations. Int J Prosthodont. 1990;3(5):430-40.

16- Khan F, Young WG, Law V, Priest J, Daley TJ. Cupped lesions of early onset dental erosion in young southeast Queensland adults. Aust Dent J. 2001;46(2):100-7.

17- Kukiattrakoon B, Hengtrakool C, Kedjarune-Leggat U. Chemical durability and microhardness of dental ceramics immersed in acidic agents. Acta Odontol Scand. 2010;68(1):1-10.

18- Kukiattrakoon B, Hengtrakool C, Kedjarune-Leggat $U$. The effect of acidic agents on surface ion leaching and surface characteristics of dental porcelains. J Prosthet Dent. 2010;103(3):148-62.

19- Kukiattrakoon B, Junpoom P, Hengtrakool C. Vicker's microhardness and energy dispersive $\mathrm{x}$-ray analysis of fluorapatite-leucite and fluorapatite ceramics cyclically immersed in acidic agents. J Oral Sci. 2009;51(3):443-50. 20- Machado C, Lacefield W, Catledge A. Human enamel nanohardness, elastic modulus and surface integrity after beverage contact. Braz Dent $\mathrm{J}$. 2008;19(1):68-72.

21- Mackert JR Jr, Evans AL. Effect of cooling rate on leucite volume fraction in dental porcelains. J Dent Res. 1991;70(2):137-9.

22- Mackert JR Jr, Rueggeberg FA, Lockwood PE, Evans AL, Thompson WO. Isothermal anneal effect on microcrack density around leucite particles in dental porcelain. J Dent Res. 1994;73(6):1221-7.

23- Magalhães, AC, Wiegand A, Rios D, Honório HM, Buzalaf MA. Insights into preventive measures for dental erosion. J Appl Oral Sci. 2009;17(2):7586.

24- Milleding P, Wennerberg A, Alaeddin S, Karlsson S, Simon E. Surface corrosion of dental ceramics in vitro. Biomaterials. 1999;20(8):733-46.

25- Piangprach T, Hengtrakool C, Kukiattrakoon B, Kedjarune-Leggat U. The effect of salivary factors on dental erosion in various age groups and tooth surfaces. J Am Dent Assoc. 2009;140(9):1137-43.

26- Raptis NV, Michalakis KX, Hirayama H. Optical behavior of current ceramic systems. Int J Periodontics Restorative Dent. 2006;26(1):31-41. 27- Serra MC, Messias DC, Turssi CP. Control of erosive tooth wear: possibilities and rationale. Braz Oral Res. 2009;23(Suppl 1):49-55.

28- Sinmazişik G, Oveçoğlu ML. Physical properties and microstructural characterization of dental porcelains mixed with distilled water and modeling liquid. Dent Mater. 2006;22(8):735-45. 